\title{
High genetic diversity and limited genetic connectivity in 2 populations of an endemic and endangered coral species: Porites sverdrupi
}

\section{Alta diversidad genética y limitada conectividad genética entre 2 poblaciones de una especie de coral endémico en peligro de extinción: Porites sverdrupi}

\author{
Violeta Martínez-Castillo ${ }^{1}$, Héctor Reyes-Bonilla ${ }^{1}$, Axayácatl Rocha-Olivares ${ }^{2}$ \\ ${ }^{1}$ Laboratorio de Sistemas Arrecifales, Departamento Académico de Ciencias Marinas y Costeras. Universidad \\ Autónoma de Baja California Sur. Carretera al sur, km 5.5, Col. El Mezquitito, CP 23080, La Paz, Baja \\ California Sur, México. \\ 2 Laboratorio de Ecología Molecular. Departamento de Oceanografia Biológica. Centro de Investigación \\ Científica y de Educación Superior de Ensenada. Carretera Ensenada-Tijuana, no. 3918, CP 22860, \\ Ensenada, Baja California, México. \\ * Corresponding author. E-mail: arocha@cicese.mx
}

\begin{abstract}
The coral Porites sverdrupi is the only scleractinian endemic to the Gulf of California. Over the last 2 decades its populations have been restricted to 3 areas, La Paz Bay, Loreto Bay, and Concepción Bay. As this species faces a high risk of extinction, there is an urgent need for biological, ecological, and genetic information for the guidance of conservation efforts. This is the first study on genetic diversity and connectivity in the species. For this, we analyzed coral colonies from Loreto Bay and Concepción Bay. Our results show that there is high genetic diversity in P. sverdrupi at both sites, with significant genetic structure between them. This condition is caused by a combination of short pelagic larval duration, low dispersal potential between the populations, and local adaptation. Our results emphasize the need for more research in order to establish adequate conservation strategies.
\end{abstract}

Key words: Gulf of California, Scleractinia, connectivity, genetic structure, RFLP.

RESUMEN. El coral Porites sverdrupi es el único coral escleractinio endémico del golfo de California. En las últimas 2 décadas sus poblaciones se han restringido a 3 áreas, bahía de La Paz, bahía de Loreto y bahía Concepción. Debido a que esta especie enfrenta un elevado riesgo de extinción, existe una urgente necesidad de generar información biológica, ecológica y genética que guíe los esfuerzos de conservación de la especie. Este es el primer trabajo sobre la diversidad y la conectividad genética en la especie, para lo cual analizamos las colonias coralinas de bahía de Loreto y bahía Concepción. Nuestros resultados muestran alta diversidad genética en ambas poblaciones de $P$. sverdrupi, con una estructura genética significativa entre ellas. Esta condición es causada por el tiempo de duración larval corto, el potencial de dispersión bajo entre las poblaciones y la adaptación local. Nuestros resultados enfatizan la necesidad de realizar más investigación para establecer estrategias adecuadas de conservación.

Palabras clave: golfo de California, Scleractinia, conectividad, estructura genética, polimorfismo de longitud de fragmentos de restricción.

\section{INTRODUCTION}

The evolutionary processes that maintain and generate variation are important, particularly so for endemic species, since an adequate level of heterozygosity may improve the adaptive potential of populations in case of environmental change (Jamieson 2007); thus, genetic diversity is positively related to the reduction of extinction risk (Frankham et al. 2002). The amount of allelic or haplotypic variability is influenced by several factors, such as gene flow among demes (connectivity), natural selection, and population size (Bolnick et al. 2011); consequently, a clear understanding of these processes is crucial for conservation efforts.

There is a wide range of studies on the use of genetic information to guide conservation efforts (Lancaster et al. 2009), many of which focus on the relation between allelic variability and the condition of endemic species, in many cases

\section{INTRODUCCIÓN}

Los procesos evolutivos que mantienen y generan variación son importantes, particularmente para especies endémicas, ya que un nivel adecuado de heterocigocidad puede mejorar el potencial adaptativo de las poblaciones frente a cambios en el ambiente (Jamieson 2007). Por lo tanto, la diversidad genética está positivamente relacionada con la reducción del riesgo de extinción (Frankham et al. 2002). El grado de variabilidad alélica o haplotípica está influenciado por diversos factores, como el flujo genético entre demes (conectividad), la selección natural y el tamaño de la población (Bolnick et al. 2011); consecuentemente, es importante entender estos procesos para llevar a cabo esfuerzos de conservación.

Existen diversos estudios que utilizan información genética para guiar esfuerzos de conservación (Lancaster et al. 
residing in marine protected areas or under exploitation. The Gulf of California is one of the areas in which this approach has been more successful. For example, it has been suggested that the survival of the only vaquita population (Phocoena sinus Norris and McFarland, 1958) depends more on human activities than on its genetic diversity, which is extremely low (Munguia-Vega et al. 2007). In commercial species, such as the leopard grouper, Mycteroperca rosacea (Streets, 1877), genetic information has been used to design no-take zones in the upper Gulf of California, which hosts high genetic diversity and could replenish nearby fishing grounds due to larval dispersal (Jackson et al. 2015). Furthermore, genetic data and oceanographic modeling have been used to highlight the importance of established marine protected areas in sustaining nearby fisheries while preserving populations of species such as the brown sea cucumber, Isostichopus fuscus (Ludwig, 1875); the leopard grouper, M. rosacea; and the snappers Hoplopagrus guentheri Gill, 1862 and Lutjanus argentiventris (Peters, 1869) (Munguia-Vega et al. 2014, Soria et al. 2014).

The coral genus Porites Link, 1807 is one of the most important reef builders in the world, containing more than 150 extant species distributed in tropical and subtropical regions (Hoeksema 2015). There are 9 Porites species in the Pacific coast of Mexico (Reyes-Bonilla 2002, Glynn et al. 2017a), including the endemic scleractinian coral of the Gulf of California: Porites sverdrupi Durham, 1947 (Chiriboga et al. 2008). The distribution of this species ranges from Ángel de la Guarda Island $\left(29^{\circ} \mathrm{N}\right)$ to Marías Islands $\left(20^{\circ} \mathrm{N}\right)$, at depths from 1 to $40 \mathrm{~m}$ (Fig. 1, Chiriboga et al. 2008). In the 1990s the species started disappearing in the south (ReyesBonilla 1993), and in the following decade the extinction of all populations south of $24^{\circ} \mathrm{N}$ was confirmed (Chiriboga et al. 2008, Reyes-Bonilla and López-Pérez 2009) and most likely due to increasing seawater temperature (Paz-García and Balart 2015). Currently there are only 3 areas where healthy populations can be found: the San Lorenzo Channel in La Paz Bay $\left(24^{\circ} \mathrm{N}\right)$, Santa Catalina Island in Loreto Bay $\left(25^{\circ} \mathrm{N}\right)$, and El Requesón Beach in Concepción Bay $\left(26^{\circ} \mathrm{N}\right)$ (Fig. 1). Among eastern Pacific Porites, P. sverdrupi is the only species with a branched morphology (López-Pérez et al. 2003), and it is usually associated with rhodolith beds in the form of free-living colonies (Reyes-Bonilla et al. 1997).

According to the Red List of the International Union for Conservation of Nature, P. sverdrupi is listed as vulnerable due to its limited distribution range and its high susceptibility to disease, bleaching, and habitat degradation (Chiriboga et al. 2008). In spite of the species' vulnerability to extinction, research has mostly focused on its taxonomy and biogeography, and much information on its biology, ecology, and genetics is therefore still missing; this lack of data complicates the establishment of efficient conservation strategies. In a first attempt to fill this information gap, we have assessed the genetic diversity and gene flow between 2 of the most important extant populations of P. sverdrupi.
2009), muchos de los cuales se centran en la relación entre la variabilidad alélica y la condición de las especies endémicas, en muchos casos residentes de áreas marinas protegidas o bajo explotación. El golfo de California es una de las regiones en las cuales este enfoque ha sido más exitoso. Por ejemplo, se ha sugerido que la supervivencia de la única población de vaquita marina (Phocoena sinus Norris y McFarland, 1958) depende más de las actividades antropogénicas que de su diversidad genética, la cual es extremadamente baja (Munguia-Vega et al. 2007). En especies comerciales, como la cabrilla sardinera, Mycteroperca rosacea (Streets, 1877), la información genética ha sido útil para diseñar zonas de no pesca en el norte del golfo de California, el cual alberga una alta diversidad genética y podría ayudar a que se recuperen zonas de pesca cercanas a través de la dispersión de larvas (Jackson et al. 2015). Además, la información genética y los modelos oceanográficos han sido de gran ayuda para señalar la importancia de las áreas marinas protegidas existentes para sostener pesquerías cercanas y conservar poblaciones de especies como el pepino de mar pardo, Isostichopus fuscus (Ludwig, 1875); la cabrilla sardinera, M. rosacea; y los pargos coconaco, Hoplopagrus guentheri Gill, 1862, y amarillo Lutjanus argentiventris (Peters, 1869) (MunguiaVega et al. 2014, Soria et al. 2014).

El género de corales Porites Link, 1807 es uno de los constructores de arrecifes más importantes del mundo, agrupando a más de 150 especies existentes en la actualidad que se distribuyen en regiones tropicales y subtropicales (Hoeksema 2015). En las costas mexicanas del Pacífico existen 9 especies de Porites (Reyes-Bonilla 2002, Glynn et al. 2017a), incluyendo el único escleractinio endémico del golfo de California: Porites sverdrupi Durham, 1947 (Chiriboga et al. 2008). Su distribución geográfica abarca desde la isla Ángel de la Guarda $\left(29^{\circ} \mathrm{N}\right)$ hasta las islas Marías $\left(20^{\circ} \mathrm{N}\right)$, a profundidades de 1 a $40 \mathrm{~m}$ (Fig. 1, Chiriboga et al. 2008). En la década de 1990, la especie comenzó a desaparecer en el sur (Reyes-Bonilla 1993), y en la década siguiente se confirmó la extinción de todas las poblaciones por debajo de los $24^{\circ} \mathrm{N}$ (Chiriboga et al. 2008, Reyes-Bonilla y López-Pérez 2009), muy probablemente como consecuencia del aumento en la temperatura del mar (Paz-García y Balart 2015). Actualmente sólo existen 3 áreas con poblaciones saludables: el canal de San Lorenzo en la bahía de La Paz $\left(24^{\circ} \mathrm{N}\right)$, la isla de Santa Catalina en la bahía de Loreto $\left(25^{\circ} \mathrm{N}\right)$ y una en la playa El Requesón en bahía Concepción $\left(26^{\circ} \mathrm{N}\right)$ (Fig. 1). Entre las especies de Porites del Pacífico oriental, P. sverdrupi es la única especie con una morfología ramificada (López-Pérez et al. 2003), y generalmente se encuentra asociada a camas de rodolitos formando colonias de vida libre (Reyes-Bonilla et al. 1997).

De acuerdo con la Lista Roja de la Unión Internacional para la Conservación de la Naturaleza, $P$. sverdrupi es una especie bajo la categoría de vulnerable debido a su limitado intervalo de distribución y a su alta susceptibilidad a enfermedades, al blanqueamiento y a la degradación de su hábitat 


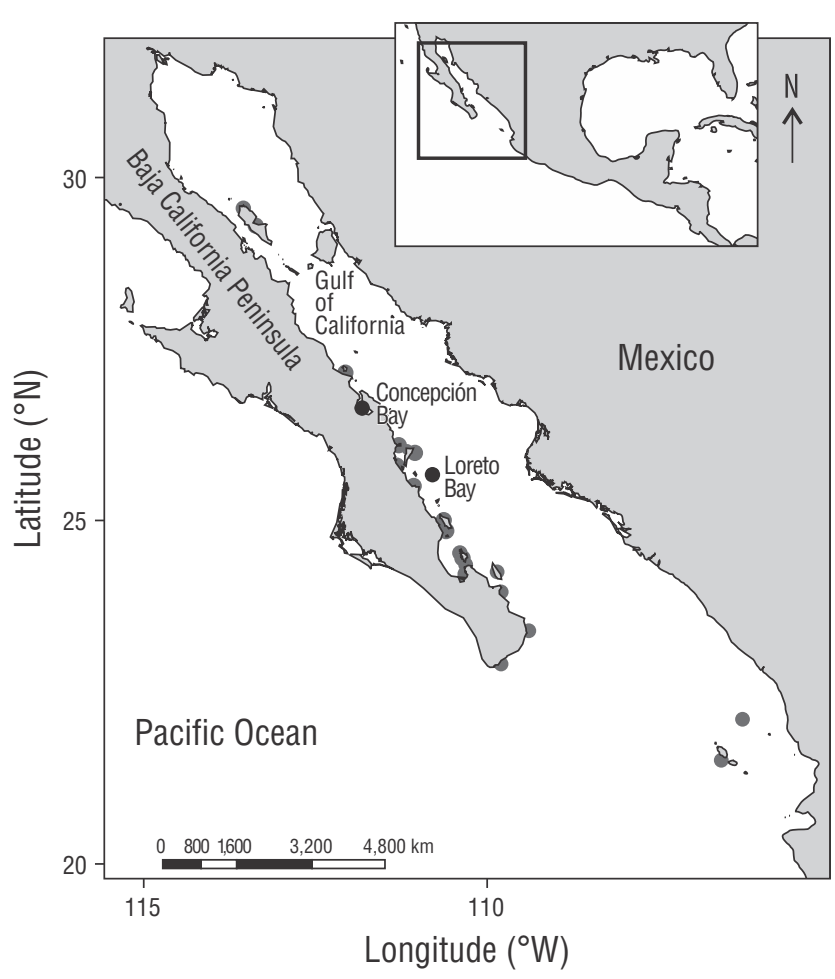

Figure 1. Distribution of Porites sverdrupi. Gray shaded areas represent the recorded historical distribution. Study sites are marked with black circles.

Figura 1. Distribución de Porites sverdrupi. El área sombreada en gris muestra la distribución histórica. Los círculos negros muestran los sitios estudiados.

\section{Materials AND METHODS}

Coral samples were collected in Concepción and Loreto bays. Corals from La Paz Bay could not be sampled because a cyclonic event prevented our team from finding them (Fortunately, we were able to find colonies in 2016, which means this population is still extant.). At each sampling site, 50 coral fragments were collected at 10 and $20 \mathrm{~m}$ depth by hand using scuba gear. Divers took care to sample from different colonies that were separated by at least $2 \mathrm{~m}$ to avoid collecting genetically identical ramets. Samples were immediately fixed in $96 \%$ alcohol and taken to the laboratory. There, lithium chloride extraction of DNA from each sample was performed, followed by amplification of the internal transcribed spacer (ITS) region (F-primer ITS4 TCCTCCGCTTATTGATATGC, R-primer ITS5 GGAAGTAAAAGTCGTAACAAGG; White et al. 1990). The resulting polymerase chain reaction (PCR) amplicons of the ITS region were digested with restriction enzymes MboI, RsaI, DpnII, and TaqI to perform a restriction fragment length polymorphism (RFLP) analysis. Restriction sites were coded for presence or absence to form composite haplotypes, from which nucleotide and haplotype diversities were computed (Nei and Tajima
(Chiriboga et al. 2008). A pesar de la alta vulnerabilidad de esta especie a la extinción, los estudios sobre este coral se han centrado principalmente en su taxonomía y biogeografía, por lo que mucha de la información sobre su biología, ecología y genética es inexistente. La falta de esta información complica la creación y el establecimiento de medidas de conservación eficientes. En un primer intento para llenar este vacío de información, evaluamos la diversidad y el flujo genético entre 2 de las poblaciones existentes más importantes de $P$. sverdrupi.

\section{MATERIALES Y MÉTOdOS}

Se recolectaron muestras de corales en bahía Concepción y bahía de Loreto. No se pudieron recolectar corales de la población de La Paz debido a que un ciclón evitó que se encontraran colonias (afortunadamente se lograron encontrar en 2016, lo que significa que aún existe esta población). En cada sitio de muestreo se recolectaron 50 fragmentos de coral de manera manual por medio de buceo autónomo entre 10 y $20 \mathrm{~m}$ de profundidad. Se cuidó que se tomaran muestras de diferentes colonias y que estas estuvieran separadas por al menos $2 \mathrm{~m}$ para evitar recolectar clones. Las muestras se fijaron inmediatamente en alcohol al $96 \%$ y se trasladaron al laboratorio para extraer el $\mathrm{ADN}$ de cada muestra por medio del protocolo de extracción en cloruro de litio. De cada extracción se amplificó la región del espaciador interno transcrito (ITS, por sus siglas en inglés) (F-primer ITS4 TCCTCCGCTTATTGATATGC, R-primer ITS5 GGAAGTAAAAGTCGTAACAAGG; White et al. 1990). Los amplicones resultantes de la reacción en cadena de la polimerasa (RCP) de la región ITS se digirieron con las enzimas de restricción MboI, RsaI, DpnII y TaqI para llevar a cabo un análisis de polimorfismo de longitud de fragmentos de restricción (PLFR). Se codificaron los sitios de restricción con base en la presencia o ausencia de éstos para formar haplotipos compuestos, con los cuales se calcularon las diversidades haplotípicas y nucleotídicas (Nei y Tajima 1981) utilizando el programa REAP 4.0 (McElroy et al. 1992). La estructura genética se estimó con un análisis de varianza molecular (AMOVA) utilizando una matriz de distancias interhaplotípicas (Nei y Tajima 1981) en el programa Arlequin (Excoffier et al. 1992). Se usó una prueba de permutaciones (10,000 iteraciones) para calcular la significación.

\section{Resultados}

La extracción de ADN fue exitosa para todas las muestras $(N=100) ;$ sin embargo, sólo se logró amplificar la región ITS de 62 fragmentos de coral: 33 de bahía Concepción y 29 de bahía de Loreto. Se observaron 10 haplotipos compuestos en ambas localidades estudiadas, 3 de los cuales fueron exclusivos de bahía Concepción y el resto se observaron en ambos sitios. Se encontraron 3 haplotipos dominantes (H4, H8 y H9): H4 fue el haplotipo dominante en bahía de Loreto (en $41 \%$ de las colonias); H9 fue el más común en bahía Concepción (en 
1981) using REAP 4.0 software (McElroy et al. 1992). An analysis of molecular variance (AMOVA) using a matrix of interhaplotypic distances (Nei and Tajima 1981) was performed to estimate genetic structure in Arlequin (Excoffier et al. 1992). Significance was computed by permutation tests $(10,000$ iterations $)$.

\section{RESULTS}

DNA extractions were successful for all samples $(N=$ 100). However, ITS amplifications were successful only in 62 fragments: 33 from Concepción Bay and 29 from Loreto Bay. A total of 10 composite haplotypes were observed in both study regions; 3 of them were exclusive to Concepción Bay, while the rest were present at both sites. There were 3 dominant haplotypes (H4, H8, and H9): H4 was dominant in Loreto Bay (in $41 \%$ of specimens); $\mathrm{H} 9$ was the most common in Concepción Bay (in 39\% of specimens); and H8 was present at both sites (Table 1).

Concepción Bay had the highest haplotype diversity $(h=0.79)$, whereas nucleotide diversity was highest in Loreto Bay $(\pi=0.20)$. Nucleotide diversity was several orders of magnitude higher among populations $(\pi=0.22)$ than within populations $(\pi=0.001$, Table 2$)$. Finally, AMOVA results showed significant genetic structure between geographic populations $\left(\Phi_{\mathrm{st}}=0.067, P=0.029\right.$, d.f. $=61$; Table 3$)$. This result was supported by a midpoint rooting neighbor-joining phylogram (Fig. 2), which divided haplotypes into 2 clades, each containing one of the haplotypes with the highest
39\% de las muestras); y $\mathrm{H} 8$ estuvo presente en ambos sitios (Tabla 1).

La diversidad haplotípica más alta se encontró en bahía Concepción $(h=0.79)$, mientras que la diversidad nucleotídica fue mayor en bahía de Loreto $(\pi=0.20)$. La diversidad nucleotídica fue más alta entre poblaciones $(\pi=0.22)$ que dentro de las mismas ( $\pi=0.001$, Tabla 2$)$. Finalmente, el AMOVA mostró una estructura genética significativa entre las poblaciones $\left(\Phi_{\mathrm{st}}=0.067, P=0.029\right.$, g.l. $=61$; Tabla 3). Este resultado se reforzó con un filograma obtenido por medio del algoritmo de neighbor-joining enraizado por punto medio (Fig. 2), el cual dividió a los haplotipos en 2 clados, cada uno con uno de los haplotipos de mayor frecuencia (H4 y H9, los cuales son representativos de bahía de Loreto y bahía Concepción, respectivamente).

\section{Discusión}

Aunque el estado taxonómico de P. sverdrupi se ha discutido ampliamente (López-Pérez et al. 2003), este es el primer trabajo sobre la variación genética de la especie. Investigaciones previas sobre la filogenia de Porites del Pacífico oriental, central y occidental, y del Caribe, han demostrado que $P$. sverdrupi está estrechamente relacionada con Porites panamensis, formando grupos recíprocamente monofiléticos (Forsman et al. 2009). A diferencia de P. sverdrupi, P. panamensis es un escleractinio ampliamente distribuido en el Pacífico oriental tropical que forma colonias incrustantes y masivas en fondos rocosos (Veron 2000).

Table 1. Haplotype frequency of Porites sverdrupi colonies at Concepción (CO) and Loreto (LO) bays.

Tabla 1. Frecuencia de haplotipos de las colonias de Porites sverdrupi en bahía Concepción (CO) y bahía de Loreto (LO).

\begin{tabular}{lccccccc}
\hline $\begin{array}{l}\text { Haplotype } \\
\text { number }\end{array}$ & $\begin{array}{l}\text { Composite } \\
\text { haplotype }\end{array}$ & CO $(N)$ & $\%$ & LO $(N)$ & $\%$ & Total $(N)$ & $\%$ \\
\hline H1 & AAAA & 1 & 3.03 & 1 & 3.45 & 2 & 3.23 \\
H2 & AAAB & 1 & 3.03 & 4 & 13.79 & 5 & 8.06 \\
H3 & AABA & 1 & 3.03 & 1 & 3.45 & 2 & 3.23 \\
H4 & AABB & $\mathbf{5}$ & $\mathbf{1 5 . 1 5}$ & $\mathbf{1 2}$ & $\mathbf{4 1 . 3 8}$ & $\mathbf{1 7}$ & $\mathbf{2 7 . 4 2}$ \\
H5* & AABC & 1 & 3.03 & 0 & 0 & 1 & 1.61 \\
H6* & ABAA & 1 & 3.03 & 0 & 0 & 1 & 1.61 \\
H7 & ABAB & 2 & 6.06 & 1 & 3.45 & 3 & 4.84 \\
H8 & ABBA & $\mathbf{6}$ & $\mathbf{1 8 . 1 8}$ & $\mathbf{9}$ & $\mathbf{3 1 . 0 3}$ & $\mathbf{1 5}$ & $\mathbf{2 4 . 1 9}$ \\
H9 & ABBB & $\mathbf{1 3}$ & $\mathbf{3 9 . 3 9}$ & $\mathbf{1}$ & $\mathbf{3 . 4 5}$ & $\mathbf{1 4}$ & $\mathbf{2 2 . 5 8}$ \\
H10* & ABBC & 2 & 6.06 & 0 & 0 & 2 & 3.23 \\
\hline Total & & 33 & 100 & 29 & 100 & 62 & 100 \\
\hline
\end{tabular}

* Private haplotypes.

Dominant haplotypes in bold. 
frequencies ( $\mathrm{H} 4$ and $\mathrm{H} 9$, representative of Loreto Bay and Concepcion Bay, respectively).

\section{Discussion}

Although the taxonomic status of $P$. sverdrupi has been discussed thoroughly (López-Pérez et al. 2003), this is the first study addressing the species' genetic variation. Previous phylogenetic research on Porites from the eastern, central, and western Pacific, and from the Caribbean, has shown that P. sverdrupi is closely related to Porites panamensis, forming reciprocally monophyletic groups (Forsman et al. 2009). Unlike $P$. sverdrupi, $P$. panamensis is a scleractinian coral that is widely distributed along the eastern tropical Pacific and forms encrusting and massive colonies over rocky bottoms (Veron 2000).

Genetic diversity is expected to be low in endemic species with small population sizes and restricted geographical distribution or in cases where each population is isolated from others (Hobbs et al. 2013). While all of these conditions apply to $P$. sverdrupi, the high levels of genetic diversity in both studied populations were unexpected $(h>0.7$, Table 2). Similar diversity values were observed in an analysis of $P$. panamensis populations from Loreto Bay, La Paz, and Cabo Pulmo $\left(23.5^{\circ} \mathrm{N}\right)$ using 2 nuclear DNA loci and 5 alloenzymatic loci as markers (Saavedra-Sotelo et al. 2013). The authors point out that populations in the Gulf of California were the most diverse in the Pacific coast of Mexico, with $h>0.6$. The described patterns suggest that high haplotype diversity in nuclear ribosomal loci may be characteristic of the genus along the western coast of the Americas.

Since the examined populations of $P$. sverdrupi were separated by over $100 \mathrm{~km}$, some level of structure was expected to be found, as the same pattern of genetic structure between relatively close populations has also been found in mollusks, marine mammals, and fish in other Pacific regions (Wood and Gardner 2007, Lancaster et al. 2009, Hobbs et al. 2013). This was indeed the case, as shown by the level of genetic distinction between local populations and the neighbor-joining phylogram (Table 3, Fig. 2). For marine species, genetic connectivity can be affected by various parameters, such as physical barriers (topography), the predominant direction and speed of marine currents, the occasional influence of anomalous movement patterns caused by events such as El Niño/ Southern Oscillation, and the oceanographic conditions (nutrients, food, water transparency) favoring the transit and colonization of a coral propagule (Wood et al. 2016). Concepción Bay receives water from the central Gulf of California, and its elongated geomorphology produces a cyclonic flow in the central area (Martínez-López and Gárate-Lizárraga 1997). This produces a retention zone, making it difficult for gametes and larvae to leave the bay and recruit elsewhere. These circumstances change during fall with an outflow from the bay because of changes in wind direction (Martínez-López
En el caso de las especies endémicas con tamaños poblacionales bajos y distribución restringida o con poblaciones aisladas, se espera que la diversidad genética sea baja (Hobbs et al. 2013). Aunque todas estas condiciones son propias de $P$. sverdrupi, nuestros resultados contrastan con lo esperado debido a los altos niveles de diversidad encontrados en ambas poblaciones estudiadas ( $h>0.7$, Tabla 2). Se han encontrado valores similares de diversidad en poblaciones de P. panamensis de Loreto, La Paz y cabo Pulmo $\left(23.5^{\circ} \mathrm{N}\right)$ utilizando 2 loci de ADN nuclear y 5 loci aloenzimáticos como marcadores moleculares (Saavedra-Sotelo et al. 2013). Los autores señalan que las poblaciones del golfo de California fueron las más diversas en las costas mexicanas del Pacífico, con valores de $h>0.6$. Este patrón sugiere que la alta diversidad haplotípica en los loci ribosomales nucleares puede ser característica del género a lo largo de la costa occidental de América.

Debido a que las poblaciones de $P$. sverdrupi estudiadas se encuentran a más de $100 \mathrm{~km}$ de distancia, se esperaba encontrar cierto grado de estructura genética entre ellas ya que el mismo patrón de estructura genética se ha encontrado en otras poblaciones cercanas de moluscos, mamíferos marinos y peces en otras regiones del Pacífico (Wood y Gardner 2007, Lancaster et al. 2009, Hobbs et al. 2013). Nuestros resultados confirman esto, como se pudo observar en los niveles de distinción genética entre poblaciones locales y el filograma de neighbor-joining (Tabla 3; Fig. 2). En especies marinas, la conectividad genética puede ser afectada por varios parámetros, como barreras físicas (topografía), la dirección y velocidad de las corrientes, la influencia ocasional de eventos como El Niño/Oscilación del Sur y la presencia de condiciones oceanográficas (nutrientes, alimento, transparencia del agua) que favorezcan el tránsito y la colonización de los propágulos larvales de coral (Wood et al. 2016). Bahía Concepción recibe agua de la parte central del golfo de California, y su geomorfología alargada produce un flujo ciclónico en la parte central (Martínez-López y Gárate-Lizárraga 1997). Esto

Table 2. Haplotype and nucleotide diversities in Porites sverdrupi. Tabla 2. Diversidades haplotípicas y nucleotídicas de Porites sverdrupi.

\begin{tabular}{lcc}
\hline & Concepción Bay & Loreto Bay \\
\hline Coral colonies $(N)$ & 33 & 29 \\
Haplotypes $(N)$ & 10 & 7 \\
Haplotype diversity $(h)$ & $0.7888 \pm 0.0369$ & $0.7211 \pm 0.0372$ \\
Nucleotide diversity $(\pi)$ & 0.0199 & 0.0206 \\
\hline $\begin{array}{l}\text { Nucleotide diversity } \\
\text { (among populations) }\end{array}$ & 0.0217 & \\
$\begin{array}{l}\text { Divergence } \\
\text { (among populations) }\end{array}$ & 0.0015 & \\
\hline
\end{tabular}


and Gárate-Lizárraga 1997). This limited potential for dispersal may contribute to the observed genetic structure.

Previous research involving eastern Pacific corals has shown that some species, such as Pocillopora damicornis and Pavona gigantea, do not exhibit genetic structure in the Gulf of California (Chávez-Romo et al. 2008, Saavedra-Sotelo et al. 2011), whereas other species, like P. panamensis, have shown significant structure inside and outside the gulf (Saavedra-Sotelo et al. 2013). Biogeographic and systematic patterns in sexual reproduction have been detected in corals, and lecithotrophic larvae produced from brooding colonies are known to have a lower dispersal potential than planktotrophic larvae produced by broadcast spawning colonies (Harrison 2011). The different reproductive traits in coral species inhabiting the same region can explain why some species such as $P$. sverdrupi and $P$. panamensis experience significant population genetic structuring while others such as $P$. damicornis and $P$. gigantea do not.

Studies on $P$. panamensis suggest that its reproductive biology is a proximal cause of the genetic differences found among populations (Paz-García et al. 2012, Saavedra-Sotelo et al. 2013). This is a gonochoric species with large shortlived planulae $(>300 \mu \mathrm{m})$, which remain in the water column for less than 2 weeks and usually settle near the parental colony (Glynn et al. 2017b). All of these features contribute to limit long-distance dispersal and therefore favor the existence of genetic differences among local populations. The pelagic larval duration of $P$. sverdrupi is unknown, but the species is phylogenetically close to P. panamensis, is also gonochoric, and produces large planulae (over $300 \mu \mathrm{m}$ ) for a short period of time (about 3 months, unpublished data). Taking all of this into consideration together with our results, particularly the presence of haplotypes specific to Concepción Bay, we suggest that $P$. sverdrupi larvae may also have a short free-living period, which would be consistent with the limited genetic exchange between populations in the central Gulf of California. The finding of 7 shared haplotypes between Loreto Bay and Concepción Bay supports some level of gene flow between populations but insufficient to homogenize the gene pool and produce a single panmictic produce una zona de retención, el cual dificulta que tanto los gametos como las larvas salgan de la bahía y se establezcan en algún otro lugar. Estas circunstancias cambian durante el otoño cuando se da un flujo hacia el exterior de la bahía, el cual es provocado por cambios en la dirección del viento (Martínez-López y Gárate-Lizárraga 1997). Este potencial de dispersión altamente limitado puede contribuir a la estructura genética observada.

Investigaciones anteriores sobre corales del Pacífico oriental han encontrado que especies como Pocillopora damicornis y Pavona gigantea no muestran estructura genética en el golfo de California (Chávez-Romo et al. 2008, Saavedra-Sotelo et al. 2011), mientras que otras como P. panamensis sí muestran estructura genética tanto dentro como fuera del golfo (Saavedra-Sotelo et al. 2013). Se han detectado patrones biogeográficos y sistemáticos en la reproducción sexual de corales, y se sabe que las larvas lecitotróficas producidas por colonias incubadoras tienen un potencial de dispersión más bajo que las larvas planctotróficas producidas por corales desovadores (Harrison 2011). Los distintos rasgos reproductivos propios de las especies de coral que viven en una misma región pueden explicar por qué algunas especies como $P$. sverdrupi y $P$. panamensis presentan una estructuración genética significativa, mientras que otras como $P$. damicornis y $P$. gigantea no.

Los estudios de $P$. panamensis sugieren que la biología reproductiva es una causa proximal de las diferencias genéticas encontradas entre sus poblaciones (Paz-García et al. 2012, Saavedra-Sotelo et al. 2013). Porites panamensis es una especie gonocórica con plánulas de corta vida y tamaño grande $(>300 \mu \mathrm{m})$, las cuales pasan menos de 2 semanas en la columna de agua y usualmente se asientan cerca de las colonias progenitoras (Glynn et al. 2017b). Todas estas características contribuyen a limitar la dispersión del coral $y$, por lo tanto, favorecen la diferenciación genética entre sus poblaciones. Se desconoce la duración pelágica larval de $P$. sverdrupi, pero se sabe que la especie es filogenéticamente cercana a $P$. panamensis, además de que también es gonocórica y produce plánulas grandes $(>300 \mu \mathrm{m})$ por periodos cortos $(\sim 3$ meses, información no publicada).

Table 3. Molecular analysis of variance for Porites sverdrupi populations (significance level based on 10,000 permutations).

Tabla 3. Análisis de varianza molecular de las poblaciones de Porites sverdrupi (nivel de significación basado en 10, 000 permutaciones).

\begin{tabular}{lcccc}
\hline Source of variation & d.f. & Sum of squares & $\begin{array}{c}\text { Variance } \\
\text { component }\end{array}$ & $\begin{array}{c}\text { Percentage of } \\
\text { variation }\end{array}$ \\
\hline Among populations & 1 & 0.033 & 0.0007 & 6.71 \\
Within populations & 60 & 0.607 & 0.0101 & 93.29 \\
Total & 61 & 0.640 & 0.0109 & \\
\hline
\end{tabular}

Fixation index $\left(\Phi_{\mathrm{ST}}\right): 0.0671(P=0.0290)$ 


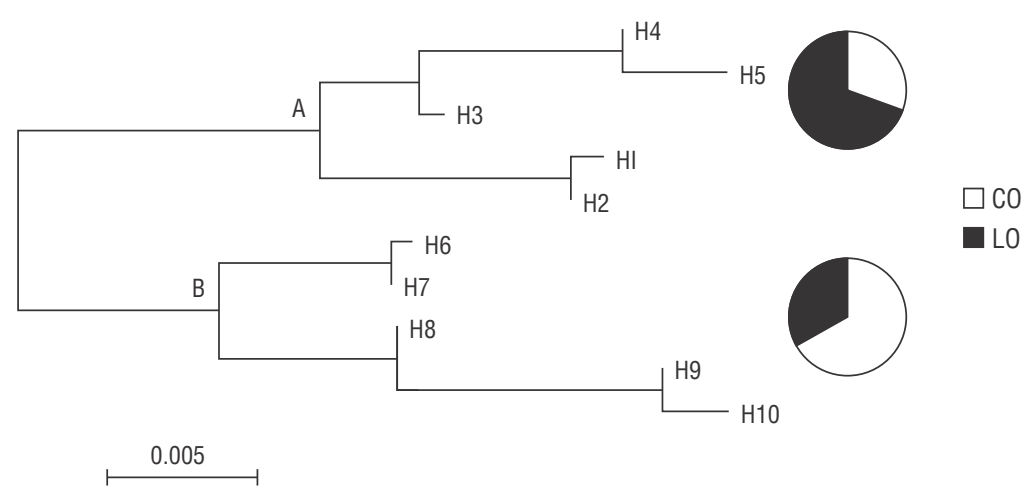

Figure 2. Neighbor-joining phylogram computed with interhaplotypic distances. Graphics show the proportion of coral colonies from each locality belonging to each clade. CO, Concepción Bay; LO, Loreto Bay.

Figura 2. Filograma neighbor-joining de distancias interhaplotípicas. Los gráficos muestran la proporción de las colonias de coral de cada localidad que pertenecen a cada clado. CO, bahía Concepción; LO, bahía de Loreto.

population. According to particle dispersal models of the Gulf of California (Marinone et al. 2016), at least 10\% of particles released from Concepción Bay between August and December will arrive to the central-southern region of the Gulf of California one month later. This, along with the predominant outflow from Concepción Bay during the fall (Martínez-López and Gárate-Lizárraga 1997), supports our hypothesis that genetic exchange probably exists but at low levels.

Geographic isolation is not the only force that contributes to genetic structure among populations. Even in the face of gene flow, selective pressures are able to create differentiation due to local adaptation (Kawecki and Ebert 2004). This scenario can explain the structure found in P. sverdrupi, for which the most relevant factor would be the particular oceanographic conditions of Concepción Bay. First, the bay has a temperature range of 18 to $35^{\circ} \mathrm{C}$, about $10^{\circ} \mathrm{C}$ wider than the one for Loreto Bay (26 to $36{ }^{\circ} \mathrm{C}$, Mateo-Cid et al. 1993), and shallower depths. Second, the physiography of Concepción Bay makes for a long residence time of water (about 34 days, Mendoza-Salgado et al. 2006). Third, the high local primary productivity can generate suboxic and even anoxic episodes in the central part of the bay. In addition, these conditions can promote the liberation of hydrogen sulfide and generate a toxic environment for several days (Rodríguez-Meza et al. 2009). Fourth, the west coast of the bay has hydrothermal vents with continuous emissions of water with very high temperature (normally over $30^{\circ} \mathrm{C}$, but up to $87^{\circ} \mathrm{C}$ ) enriched with metals such as arsenic, boron, barium, cesium, iron, mercury, iodine, lithium, silicon, and strontium (Oporto-Guerrero et al. 2016). This environmental setting, to which the colonies of $P$. sverdrupi must adapt, may act as a selective barrier for the survival of individuals from other areas that may present very different physiological traits. Migrants from elsewhere would be able to arrive and settle inside Concepción Bay, but their survival, recruitment, and successful reproduction may be compromised. In short, the remarkably distinct environments prevailing in the 2 study areas could
Tomando en cuenta todas estas características y nuestros resultados, particularmente la presencia de haplotipos privados en bahía Concepción, sugerimos que las larvas de $P$. sverdrupi también deben poseer un periodo de vida libre corto, lo cual sería consistente con el intercambio genético limitado entre las poblaciones de la parte central del golfo de California. Los 7 haplotipos compartidos entre bahía Concepción y bahía de Loreto indican cierto nivel de flujo genético entre las poblaciones, aunque insuficiente para homogeneizar y producir una población panmíctica. De acuerdo con los modelos de dispersión de partículas en el golfo (Marinone et al. 2016), al menos $10 \%$ de las partículas liberadas en bahía Concepción entre agosto y diciembre llegarán a la región centro-sur del golfo un mes después. Esto, en conjunto con el flujo predominante hacia el exterior de bahía Concepción en otoño (Martínez-López y Gárate-Lizárraga 1997), apoya nuestra hipótesis de que probablemente existe cierto intercambio genético, aunque en niveles bajos.

El aislamiento geográfico no es la única fuerza que contribuye a generar estructura genética entre poblaciones. Incluso ante la presencia de flujo genético, las presiones selectivas pueden crear diferenciación por medio de la adaptación local (Kawecki y Ebert 2004). Este escenario también puede explicar la estructura encontrada en $P$. sverdrupi, para la cual las condiciones oceanográficas particulares de bahía Concepción son el factor más importante. Primero, la bahía posee un intervalo de temperatura que va de 18 a $35^{\circ} \mathrm{C}$, alrededor de 10 grados más amplio que en la bahía de Loreto (26 a $36{ }^{\circ} \mathrm{C}$, Mateo-Cid et al. 1993), y a profundidades más someras. Segundo, la fisiografía de bahía Concepción provoca un largo tiempo de residencia del agua (alrededor de 34 días, Mendoza-Salgado et al. 2006). Tercero, la alta productividad primaria puede generar episodios subóxicos y anóxicos en la parte central de la bahía. Además, estas condiciones pueden promover la liberación de sulfuro de hidrógeno, provocando un ambiente tóxico por algunos días (Rodríguez-Meza et al. 2009). Cuarto, la costa occidental de la bahía presenta 
also be contributing to the observed genetic distinction of populations evolving independently.

The coral P. sverdrupi is an endemic, vulnerable species, and one of the purposes of this research was to link our results with conservation efforts. Although the original geographic range of $P$. sverdrupi spanned over $500 \mathrm{~km}$ (Fig. 1), by the 1990s the species started disappearing in the south (Reyes-Bonilla 1993). In the following decade, the extinction of all populations south of $24^{\circ} \mathrm{N}$ was confirmed (Chiriboga et al. 2008, Reyes-Bonilla and López-Pérez 2009). Our results do not evidence low genetic diversity in the species (Table 2 ) and suggest that gene flow, although limited, must exist between populations. These are not typical conditions of a species undergoing extinction or one that has suffered a severe contraction of its effective population size, where low demographic sizes generally lead to a loss of genetic variability due to drift and to the high probability of inbreeding involving further depression of genetic variability. This discrepancy may mean that $P$. sverdrup $i$ has a high rate of effective sexual reproduction and a small proportion of clones. Further research on this subject must be done to confirm our hypothesis.

Due to the genetic differentiation between the studied populations, and the high risk of extinction of this species in the Gulf of California, these populations should be considered important for conservation purposes. Strategies to improve their condition, such as restoration, must be developed. Also, we strongly recommend the incorporation of this coral species into the NOM-059-SEMARNAT-2010 (the official Mexican regulation for endangered species) because it fits the conditions for inclusion due to its low genetic connectivity, limited range of distribution, small population sizes, and high susceptibility to disease. Along with official regulations and restoration, research on the biology and ecology of this endemic coral is essential in any attempt to preserve the species. Fortunately, some of these studies are currently being carried out and new biological data for this species are being obtained in the field.

In conclusion, the 2 studied populations of $P$. sverdrupi exhibited high genetic diversity. A total of 10 haplotypes were found in 62 analyzed colonies, all of which appeared at Concepción Bay ( 3 of them are unique to the area) and 7 were shared between this area and Loreto Bay. We suggest that the genetic structure between populations is probably caused by a combination of short pelagic larval duration, potentially low connectivity among populations, and local adaptation. Although the species populations have been suffering a steady decline in recent decades, genetic data do not show signs of genetic erosion, and further investigation is needed to fully understand the population dynamics and processes of this species.

\section{ACKNowledgments}

This research was funded by grants from Centro de Investigación Científica y de Educación Superior de Ensenada ventilas hidrotermales que continuamente emiten agua con temperaturas altas (normalmente arriba de $\operatorname{los} 30{ }^{\circ} \mathrm{C}$ y hasta $87^{\circ} \mathrm{C}$ ) enriquecida con metales como arsénico, boro, bario, cesio, hierro, mercurio, yodo, litio, silicio y estroncio (Oporto-Guerrero et al. 2016). El ambiente al cual P. sverdrupi se tiene que adaptar puede actuar como una barrera selectiva en la supervivencia de individuos provenientes de otras áreas con rasgos fisiológicos diferentes. Las larvas migrantes serían capaces de llegar y asentarse en bahía Concepción, pero su supervivencia, reclutamiento y éxito reproductivo estarían comprometidos. En concreto, los ambientes notablemente diferentes propios de cada sitio estudiado contribuyen a la distinción genética observada en poblaciones que evolucionan de manera independiente.

El coral P. sverdrupi es una especie endémica y vulnerable, y uno de los objetivos del presente trabajo fue brindar información que ayude a los esfuerzos de conservación. Aunque la distribución original de la especie se extiendía en más 500 km (Fig. 1), a partir de la década de 1990 la especie comenzó a desaparecer en el sur (Reyes-Bonilla 1993). En la siguiente década se confirmó la extinción de todas las poblaciones al sur de $24^{\circ} \mathrm{N}$ (Chiriboga et al. 2008, Reyes-Bonilla y López-Pérez 2009). Nuestros resultados no muestran una baja diversidad genética en la especie (Tabla 2) y sugieren que existe cierto nivel de flujo genético (aunque bajo). Estas no son las condiciones típicas de una especie en extinción o que ha sufrido una severa contracción de su tamaño efectivo de población, donde las bajas densidades demográficas llevan a una pérdida de variabilidad genética debido a la deriva y a una alta probabilidad de endogamia que lleva a un estado de erosión alélica. Esta discrepancia puede significar que las poblaciones de $P$. sverdrupi poseen una tasa elevada de reproducción sexual efectiva y una baja proporción de clones. Para confirmar nuestra hipótesis, se debe realizar más investigación.

Las poblaciones estudiadas deben ser consideradas importantes en los esfuerzos de conservación debido a la diferenciación genética entre ambas y al alto riesgo de extinción de la especie en el golfo de California. Acciones como la restauración deben desarrollarse para mejorar su condición. Por lo mismo, recomendamos la inclusión de esta especie de coral en la NOM-059-SEMARNAT-2010 (la Norma Oficial Mexicana para la protección de especies en riesgo) debido a que cumple con las condiciones de inclusión: conectividad genética limitada, distribución reducida, tamaños poblacionales bajos y alta susceptibilidad a enfermedades. Sumado a las regulaciones oficiales y la restauración, es necesario realizar más investigación sobre la biología y ecología de esta especie de coral endémico que ayude y guíe los esfuerzos para la conservación de esta especie. Afortunadamente, algunos de estos estudios ya se están llevando a cabo y se está obteniendo nueva información de la especie.

En conclusión, las 2 poblaciones estudiadas de $P$. sverdrupi presentaron una alta diversidad genética. Se encontraron 10 haplotipos en las 62 colonias analizadas, de los cuales 3 
(CICESE 625112) to ARO, and Consejo Nacional de Ciencia y Tecnología (Mexico, Proyecto Fronteras en la Ciencia 278) to HRB. Nancy Saavedra (Universidad Autónoma de Sinaloa) and Jorge Montano (Universidad Autónoma de Querétaro) helped with laboratory work. Eduardo Balart (Centro de Investigaciones Biológicas del Noroeste) and Damien Olivier (Universidad Autónoma de Baja California Sur) gave valuable comments in preliminary versions of this paper. The authors thank an anonymous reviewer for the valuable comments that improved this manuscript. While writing the manuscript, the first author received a master's degree scholarship from the Consejo Nacional de Ciencia y Tecnología (ID 332939).

\section{REFERENCES}

Bolnick DI, Amarasekare P, Araújo MS, Bürger R, Levine JM, Novak M, Rudolf VHW, Schreiber SJ, Urban MC, Vasseur DA. 2011. Why intraspecific trait variation matters in community ecology. Trends Ecol. Evol. 26(4): 183-192. https://doi.org/10.1016/j.tree.2011.01.009

Chávez-Romo HE, Correa-Sandoval F, Paz-García DA, ReyesBonilla H, López-Pérez RA, Medina-Rosas P, Hernández-Cortés MP. 2008. Genetic structure of the scleractinian coral, Pocillopora damicornis, from the Mexican Pacific. In: Riegl B, Dodge RE (eds.), Proceedings of the 11th International Coral Reef Symposium, 7-11 Jul 2008. Fort Lauderdale (FL), pp.429-433.

Chiriboga A, Edgar G, Reyes-Bonilla H. 2008. Porites sverdrupi. The IUCN Red List of Threatened Species 2008: e.T133512A3781140.

http://dx.doi.org/10.2305/IUCN.UK.2008.RLTS. T133512A3781140.en

Excoffier L, Smouse PE, Quattro JM. 1992. Analysis of molecular variance inferred from metric distances among DNA haplotypes: Application to human mitochondrial DNA restriction data. Genetics 131(2): 479-491.

Forsman ZH, Barshis DJ, Hunter CL, Toonen RJ. 2009. Shapeshifting corals: Molecular markers show morphology is evolutionarily plastic in Porites. BMC Evol. Biol. 9(1): 45. https://doi.org/10.1186/1471-2148-9-45

Frankham R, Ballou JD, BriscoeDA. 2002. Introduction to Conservation Genetics. Cambridge University Press, UK, 617 pp.

Glynn PW, Alvarado JJ, Banks S, Cortés J, Feingold JS, Jiménez C, Maragos JE, Martínez P, Maté JL, Moanga DA, et al. 2017a. Eastern Pacific coral reef provinces, coral community structure and composition: an overview. In: Glynn PW, Manzello DP, Enochs IC (eds.), Coral Reefs of the Eastern Tropical Pacific. Coral Reefs of the World 8. Springer, pp. 107-176. https://doi.org/10.1007/978-94-017-7499-4_5

Glynn PW, Colley SB, Carpizo-Ituarte E, Richmond RH. 2017 b. Coral reproduction in the Eastern Pacific. In: Glynn PW, Manzello DP, Enochs IC (eds.), Coral Reefs of the Eastern Tropical Pacific, Coral Reefs of the World, vol. 8, Springer, pp. 435-476.

https://doi.org/10.1007/978-94-017-7499-4_15

Harrison PL. 2011. Sexual reproduction of scleractinian corals. In: Dubinsky Z, Stambler N. (eds.), Coral Reefs: an Ecosystem in Transition. Springer, USA, pp. 59-85. https://doi.org/10.1007/978-94-007-0114-4_6

Hobbs JPA, van Herwerden L, Jerry DR, Jones GP, Munday PL. 2013. High genetic diversity in geographically remote populations of endemic and widespread coral reef angelfishes (genus: Centropyge). Diversity 5(1): 39-50. https://doi.org/10.3390/d5010039 fueron exclusivos de bahía Concepción y el resto se encontraron en ambas localidades. Sugerimos que la estructura genética encontrada entre las poblaciones se debe probablemente a los periodos larvarios pelágicos cortos, la baja conectividad entre las poblaciones y la adaptación local. Aunque las poblaciones de la especie han disminuido constantemente en las últimas décadas, la información genética no evidencia la erosión genética, y se necesita hacer más investigación para entender la dinámica de sus poblaciones y los procesos de la especie.

\section{Agradecimientos}

El presente trabajo se llevó a cabo gracias al financiamiento del Centro de Investigación Científica y de Educación Superior de Ensenada a cargo de ARO (CICESE 625112) y a los fondos otorgados por el Consejo Nacional de Ciencia y Tecnología (México, Proyecto Fronteras de la Ciencia 278) a HRB. Agradecemos a Nancy Saavedra (Universidad Autónoma de Sinaloa) y a Jorge Montano (Universidad Autónoma de Querétaro) su ayuda con el trabajo de laboratorio. Eduardo Balart (Centro de Investigaciones Biológicas del Noroeste) y Damien Olivier (Universidad Autónoma de Baja California Sur) leyeron y mejoraron la versión preliminar de este manuscrito. Agradecemos también a un revisor anónimo los comentarios que mejoraron la calidad del manuscrito. Durante la escritura del presente, la primera autora recibió una beca de maestría del Consejo Nacional de Ciencia y Tecnología (becaria 332939).

Hoeksema B. 2015. Porites Link, 1807. In: WoRMS Editorial Board (eds.), World Register of Marine Species. [accessed on 22 November 2016]. http://www.marinespecies.org/aphia. php? $\mathrm{p}=$ taxdetails\&id $=288916$.

Jackson AM, Munguía-Vega A, Beldade R, Erisman BE, Bernardi G. 2015. Incorporating historical and ecological genetic data for leopard grouper (Mycteroperca rosacea) into marine reserve design in the Gulf of California. Conserv. Genet. 16(4): 811822.

https://doi.org/10.1007/s10592-015-0702-8

Jamieson IG. 2007. Has the debate over genetics and extinction of island endemics truly been resolved? Anim. Conserv. 10(2): 139-144. https://doi.org/10.1111/j.1469-1795.2006.00095.x

Kawecki TJ, Ebert D. 2004. Conceptual issues in local adaptation. Ecol. Lett. 7(12): 1225-1241. https://doi.org/10.1111/j.1461-0248.2004.00684.x

Lancaster ML, Arnould JPY, Kirkwood R. 2009. Genetic status of an endemic marine mammal, the Australian fur seal, following historical harvesting. Anim. Conserv. 13(3): 247-255. https://doi.org/10.1111/j.1469-1795.2009.00325.x

López-Pérez RA, Reyes-Bonilla H, Budd AF, Correa-Sandoval F. 2003. The taxonomic status of Porites sverdrupi, an endemic coral of the Gulf of California = Posición taxonómica de Porites sverdrupi, coral endémico del Golfo de California. Cienc. Mar. 29(4B): 677-691.

https://doi.org/10.7773/cm.v29i42.184 
Marinone G, Montaño C, Valenzuela E. 2016. Conectividad y dispersión en el Golfo de California. Centro de Investigación Científica y de Educación Superior de Ensenada, Ensenada, Mexico. http://conectividad-dispersion.cicese.mx/.

Martínez-López A, Gárate-Lizárraga I. 1997. Variación diurna de la materia orgánica particulada en una laguna costera del Golfo de California. Rev. Biol. Trop. 45(4): 1421-1428.

Mateo-Cid LE, Sánchez-Rodríguez I, Rodríguez-Montesinos YE, Casas-Valdez MM. 1993. Floristic study on benthic marine algae of Bahia Concepcion, BCS, Mexico = Estudio florístico de las algas marinas bentónicas de Bahía Concepción, BCS, México. Cienc. Mar. 19(1): 41-60. http://doi.org/10.7773/cm.v19i1.921

McElroy D, Moran P, Bermingham E, Kornfield I. 1992. REAP: The Restriction Enzyme Package. Department of Zoology. Migratory Fish Research Institute and Center for Marine Studies, University of Maine, Orono (ME).

Mendoza-Salgado RA, Lechuga-Devéze $\mathrm{CH}$, Ortega-Rubio A. 2006. Influence of rainfall on a subtropical arid zone coastal system. J. Arid Environ. 66(2): 247-256. https://doi.org/10.1016/j.jaridenv.2005.11.005

Munguia-Vega A, Esquer-Garrigos Y, Rojas-Bracho L, VazquezJuarez R, Castro-Prieto A, Flores-Ramirez S. 2007. Genetic drift vs. natural selection in a long-term small isolated population: major histocompatibility complex class II variation in the Gulf of California endemic porpoise (Phocoena sinus). Mol. Ecol. 16(19): 4051-4065. https://doi.org/10.1111/j.1365-294x.2007.03319.x

Munguia-Vega A, Jackson A, Marinone SG, Erisman B, MorenoBaez M, Girón-Nava A, Pfister T, Aburto-Oropeza O, Torre J. 2014. Asymmetric connectivity of spawning aggregations of a commercially important marine fish using a multidisciplinary approach. PeerJ 2: e511. https://doi.org/10.7717/peerj.511

Nei M, Tajima F. 1981. DNA polymorphism detectable by restriction endonucleases. Genetics 97(1): 145-163.

Oporto-Guerrero T, Reyes-Bonilla H, Ladah LB. 2016. Presence of the reef-building coral, Porites panamensis, in a shallow hydrothermal field in the Gulf of California. Mar. Biodiv. 1-6. https://doi.org/10.1007/s12526-016-0546-6

Paz-García DA, Balart EF. 2015. New record of the endemic coral Porites sverdrupi (Gulf of California): do fluctuations in seawater temperature regulate its southernmost range limit? Mar. Biodiv. 46(2): 499-502. https://doi.org/10.1007/s12526-015-0375-Z

Paz-García DA, Chávez-Romo HE, Correa-Sandoval F, ReyesBonilla H, López-Pérez A, Medina-Rosas P, Hernández-Cortés MP. 2012. Genetic connectivity patterns of corals Pocillopora damicornis and Porites panamensis (Anthozoa: Scleractinia) along the west coast of Mexico. Pac. Sci. 66(1): 43-61. https://doi.org/10.2984/66.1.3

Reyes-Bonilla H. 1993. Biogeografía y ecología de los corales hermatípicos del Pacífico de México. In: Salazar-Vallejo SJ,
González NE (eds.), Biodiversidad Marina y Costera de México. CONABIO/CIQRO, Chetumal, pp. 202-227.

Reyes-Bonilla H. 2002. Checklist of valid names and synonyms of stony corals (Anthozoa: Scleractinia) from the eastern Pacific. J. Nat. Hist. 36(1): 1-13. https://doi.org/10.1080/713833841

Reyes-Bonilla H, López-Pérez RA. 2009. Corals and coral reef communities in the Gulf of California. In: Johnson A, LedezmaVázquez J (eds.), Atlas of Coastal Ecosystems in the Western Gulf of California. The University of Arizona Press, pp. 45-57.

Reyes-Bonilla H, Riosmena-Rodriguez R, Foster MS. 1997. Hermatypic corals associated with rhodolith beds in the Gulf of California, México. Pac. Sci. 51(3): 328-337.

Rodríguez-Meza GD, Shumilin E, Sapozhnikov D, MéndezRodríguez L, Acosta-Vargas B. 2009. Evaluación geoquímica de elementos mayoritarios y oligoelementos en los sedimentos de Bahía Concepción (BCS, México). Bol. Soc. Geol. Mex. 61(1): 57-72. https://doi.org/10.18268/bsgm2009v61n1a6

Saavedra-Sotelo NC, Calderón-Aguilera LE, Reyes-Bonilla H, López-Pérez RA, Medina-Rosas P, Rocha-Olivares A. 2011. Limited genetic connectivity of Pavona gigantea in the Mexican Pacific. Coral Reefs 30(3): 677-686. https://doi.org/10.1007/s00338-011-0742-6

Saavedra-Sotelo NC, Calderon-Aguilera LE, Reyes-Bonilla H, Paz-García DA, López-Pérez RA, Cupul-Magaña A, CruzBarraza JA, Rocha-Olivares A. 2013. Testing the genetic predictions of a biogeographical model in a dominant endemic Eastern Pacific coral (Porites panamensis) using a genetic seascape approach. Ecol. Evol. 3(12): 4070-4091. https://doi.org/10.1002/ece3.734

Soria G, Torre-Cosio J, Munguia-Vega A, Marinone SG, Lavín MF, Cinti A, Moreno-Báez M. 2014. Dynamic connectivity patterns from an insular marine protected area in the Gulf of California. J. Mar. Syst. 129: 248-258. https://doi.org/10.1016/j.jmarsys.2013.06.012

Veron J. 2000. Corals of the world. Vol 3. Australian Institute of Marine Science. Townsville, MC, Australia, $490 \mathrm{pp}$.

White TJ, Bruns T, Lee S, Taylor J. 1990. Amplification and direct sequencing of fungal ribosomal RNA genes for phylogenetics. In: Innis MA, Gelfand DH, Sninsky JJ, White TJ (eds.), PCR protocols: A Guide to Methods and Applications. Academic Press, San Diego, pp. 315-322. https://doi.org/10.1016/b978-0-12-372180-8.50042-1

Wood AR, Gardner JPA. 2007. Small spatial scale population genetic structure on two limpet species endemic to the Kermadec Islands, New Zealand. Mar. Ecol.:Prog. Ser. 349: 159-170. https://doi.org/10.3354/meps07110

Wood S, Baums IB, Paris CB, Ridgwell A, Kessler WS, Hendy EJ. 2016. El Niño and coral larval dispersal across the eastern Pacific marine barrier. Nat. Commun. 7: 12571. https://doi.org/10.1038/ncomms12571

Received April 2017, Accepted September 2017. 